Tanjungpura Law Journal, Vol. 3, Issue 2, July 2019: 107 - 125

ISSN Print: 2541-0482 | ISSN Online: 2541-0490

Open Access at: http://jurnal.untan.ac.id/index.php/tli

Article Info

Submitted: 20 Mei 2018 | Reviewed: 17 April 2019 | Accepted: 19 Juni 2019

\title{
BISNIS DAN HAK ASASI MANUSIA: APA YANG DILAKUKAN ASEAN?
}

\author{
Muhammad Insan Tarigan 1
}

\begin{abstract}
Multinational corporations (MNCs) are business actors who have activities beyond a country's boundaries. This MNCs activities cannot be denied to have an influence on human social life, one of them is human rights. With those regards, regulations at international level have difficulties, because MNCs have not been recognized as the subject of international law. Furthermore, in the context of human rights, MNCs cannot be held accountable, because in this case only the country as the duty bearer of human rights. These conditions make no rules that can bind MNCs behavior to human rights. This article will focus on discussing how the international community takes action on business and human rights issues and the measures that ASEAN can take to engage in business and human rights issues in Southeast Asia. Although, there are some international rules that are born from various international cooperation, but the nature of the rule is the majority of soft law. These business and human rights issues became the international community's attention for a long time until finally the United Nations (UN) Representative made UN Guiding Principles, which also known as Ruggie's Principles. Southeast Asia through AICHR can take several actions to advance the protection of human rights related to business activities as contained in UNGPs and Ruggie's principles, such as AICHR can undertake study literature, encourage Member States to take effective action, engage in dialogue and consultation with organs of ASEAN, community organizations, and other stakeholders, and create a binding legal instrument concerning business and human rights.
\end{abstract}

Keywords: ASEAN; business and human rights; ruggie's principles

\begin{abstract}
Abstrak
Multinational corporations (MNCs) merupakan pelaku bisnis yang memiliki aktivitas melewati batas suatu negara. Kegiatan MNCs ini tidak bisa dipungkiri memiliki pengaruh terhadap kehidupan sosial manusia, salah satunya hak asasi manusia (HAM). Pengaturan di tingkat internasional mengalami kesulitan, karena MNCs belum diakui sebagai subjek hukum internasional. Kemudian dalam konteks HAM, MNCs tidak dapat dimintai pertanggungjawaban, karena dalam hal ini hanya negaralah sebagai pemegang kewajiban (duty bearer) HAM. Kondisi tersebut membuat tidak ada aturan yang mengikat perilaku MNc terhadap HAM. Artikel ini akan fokus mendiskusikan bagaimana masyarakat internasional mengambil tindakan terhadap permasalahan bisnis dan HAM serta langkah-langkah yang dapat dilakukan oleh ASEAN untuk ikut membicarakan bisnis dan HAM di Asia Tenggara. Meskipun, ada beberapa aturan internasional yang lahir dari berbagai kerjasama internasional, tetapi sifat dari aturan tersebut mayoritas soft law. Persoalan bisnis dan HAM ini menjadi perhatian masyarakat internasional dalam jangka waktu yang lama hingga pada akhirnya Perwakilan Bangsa-Bangsa (PBB) membuat UN Guiding Principles yang juga dikenal sebagai Ruggie's Principles. Asia Tenggara melalui AICHR dapat melakukan beberapa langkah untuk memajukan perlindungan HAM yang berkaitan dengan aktivitas bisnis seperti yang tertuang di dalam UNGPs dan Ruggie's principles,
\end{abstract}

\footnotetext{
${ }^{1}$ Fakultas Hukum, Universitas Surabaya, Jalan Raya Kalirungkut, Surabaya, 80293, Jawa Timur, Indonesia, email:insantarigan02@gmail.com, Tel./Fax.081273116200.
} 
seperti AICHR dapat melakukan study literature, mendorong negara-negara anggota untuk mengambil tindakan yang efektif, melaksanakan dialog dan konsultasi dengan organ-organ ASEAN, organisasi kemasyarakatan, dan stakeholder yang lain, serta membuat instrument hukum yang mengikat tentang bisnis dan HAM.

\section{Kata Kunci: ASEAN; bisnis dan hak asasi manusia; ruggie's principles}

\section{Pendahuluan}

\section{Multinational corporations}

(MNCs) memiliki peran yang sangat signifikan di dalam hubungan yang bersifat global. Tetapi, ada kesulitan untuk mengatur MNCs baik di tingkat domestik maupun internasional. ${ }^{2}$ MNCs adalah entitas yang menghasilkan keuntungan dari kegiatan produksi barang dan jasa yang dapat beroperasi di beberapa negara sekaligus. ${ }^{3}$ MNCs juga dapat dengan mudah berpindah negara operasi dari satu negara ke negara lainnya yang menawarkan keuntungan yang lebih besar. ${ }^{4}$ Dengan kondisi demikian, maka sering kali negara tempat beroperasinya MNCs akan mengalah dengan mempermudah regulasi agar MNCs semakin nyaman untuk melakukan kegiatan bisnisnya. Kondisi tersebut telah menjadi perhatian untuk waktu yang lama bahwa kegiatan ekonomi MNCs di negara berkembang dengan standar pengaturan yang

\footnotetext{
2 Imam Prihandono. 2011. "Transnational Corporations and Human Rights: Strengthening Current Tools to Promote Accountability". Transnational Corporations Review. 3 (3): 73

${ }^{3}$ Kenneth A. Reinert, et al, 2016. "The New OECD Guidelines for Multinational Enterprises: Better but Not Enough". Development in Practice. 26 (6): 816.

${ }^{4}$ Imam Prihandono. loc. cit.
}

lemah. 5 Terlebih lagi bahwa pada umumnya negara tujuan MNCs adalah negara-negara berkembang.

Pengaturan di tingkat internasional juga mengalami kesulitan, karena MNCs sampai saat ini belum diakui sebagai subjek hukum internasional, meskipun mereka berperan dalam hubungan yang bersifat global. Oleh karena itu, MNCs tidak memiliki personalitas hukum. ${ }^{6}$ Artinya MNCs tidak dapat diminta pertanggungjawaban atas pelanggaran yang dilakukannya di dalam pengadilan internasional. Walaupun yang paling ideal untuk mengatur MNCs ini adalah melalui mekanisme internasional, karena dilihat dari ruang lingkup beroperasinya skala internasional. Tetapi pada akhirnya, korban atas pelanggaran yang dilakukan oleh MNCs menjadi subjek yang paling dirugikan akibat dari tidak adanya kepastian hukum di level internasional.

Terjadi sebuah peningkatan korporasi yang sangat luas di era

\footnotetext{
5 Carola Glinski. 2017. "The Ruggie Framwork, Business Human Rights Self-Regulation and Torts Law: Increasing Standards through Mutual Impact and Learning". Nordic Journal of Human Rights 35 (1): 15 .

${ }^{6}$ Imam Prihandono. loc. cit
} 
modern yang telah terjadi dari tahun 1980an. Ada sekitar 7.000 induk perusahaan multinasional yang telah tercatat, trend tersebut kemudian meningkat drastis menjadi sekitar 60.000 pada tahun 2001 yang mengendalikan lebih dari 800.000 anak perusahaan asing. Kemudian, telah terbukti bahwa ada sekitar $51 \%$ dari 100 entitas terkaya di dunia dimiliki oleh korporasi. Dengan kekuatan finansial dan asset yang dimilikinya, MNCs dapat mempengaruhi politik dalam negeri negara-negara yang ada di dunia, khususnya di bidang industri, serta kebijakan internasional maupun domestik yang berkaitan dengan kesehatan, lingkungan, teknologi, dan beberapa sektor kehidupan lainnya, termasuk juga HAM. ${ }^{7}$ Sedangkan sektor HAM ini juga mencakup banyak hal, seperti hak para pekerja, polusi lingkungan hidup, sengketa lahan, dan banyak yang lainnya. MNCs terkadang lupa memperhatikan kehidupan sosial dan lingkungan sekitar karena terlalu bersemangat untuk mencari keuntungan. Kemudian ada anggapan dari MNCs bahwa HAM hanyalah tanggungjawab negara. MNCs dalam mencari keuntungan hanya memikirkan dirinya sendiri. Dalam sebuah ilustrasi yang terkenal Adam Smith menegaskan

\footnotetext{
${ }^{7}$ Danwood Mzikenge Chirwa. 2017. “The Long March to Binding Obligations Transnational Corporations in International Human Rights Law". South African Journal on Human Rights. 22 (1): 80.
}

109 bahwa:8

"Kita makan bukan karena kebaikan si tukang roti, tukang roti atau si tukang daging, melainkan karena sifat mementingkan diri sendiri yang ada di dalam diri mereka. Kita bukan mengharapkan cinta mereka terhadap orang lain, melainkan cinta mereka terhadap dirinya sendiri."

Ilustrasi tersebut terkadang tercermin pada MNCs dan semakin berdampak negatif karena tidak adanya aturan yang mengikat perilaku MNCs terhadap HAM. Sebenernya, upaya untuk mengatur kegiatan MNCs telah dimulai sejak akhir tahun 1960an. Misalnya, pada 1969, sebuah panel yang diadakan oleh Seketaris Jenderal Perserikatan Bangsa-Bangsa (Sekjen PBB) yang dipimpin langsung oleh Economic and Social Counsel (ECOSOC) untuk memahami sebuah "Agreed Statement"s yang diartikan beberapa pemahaman dan langkah-langkah yang harus diperhatikan oleh MNCs. ${ }^{10}$ Meskipun pengaturan tersebut belum membahas tentang Hak Asasi Manusia (HAM) lebih mendalam. Sebenarnya, diskusi tentang pembicaraan dan pemajuan HAM secara

\footnotetext{
${ }^{8}$ Ade Maman Suherman. 2014. Hukum Perdagangan Internasional: Lembaga Penyelesaian Sengketa WTO dan Negara Berkembang. Jakarta: Sinar Grafika. hlm. 6.

${ }^{9}$ Dua hal yang disepakati adalah bahwa MNCs harus mengetahui tujuan pembangunan negara tuan rumah dan tujuan tersebut harus berdasarkan pengertian negara tuan rumah bukan berdasarkan perspektif MNCs tersebut.

${ }^{10}$ Kenneth A. Reinert, et al. op. cit. hlm. 817
} 
tradisional telah dipusatkan hanya kepada hubungan antara negara dan dan warga negaranya. Tetapi, pada akhirnya pembicaraan HAM berkembang kepada kegiatan bisnis karena dampak sosial dari kegiatan perusahaan semakin jelas bagi individu, kelompok masyarakat dan pembuat kebijakan. ${ }^{11}$ Upaya internasional untuk memperkenalkan HAM, kewajiban sosial dan lingkungan kepada MNCs melalui mekanisme internasional klasik sejak tahun 1970an baik yang bersifat soft law ${ }^{12}$ maupun mekanisme yang dibuat berdasarkan kerjasama MNCs secara sukarela, ${ }^{13}$ meskipun keduanya dianggap gagal. ${ }^{14}$ The OECD Guidelines for Multinational Enterprises ${ }^{15}$ dan the ILO Declaration on Fundamental Principles and Rights at Work. ${ }^{16}$ UN Global Compact merupakan

11 Geordan Graetz and Daniel M. Franks. 2013. "Incorporating Human Rights into the Corporate Domain: Due Diligence, Impact Assessment and Integrated Risk Management". Impact Assesment and Project Apparsial. 31 (2): 97.

12 Lihat the OECD Guidelines for Multinational Corporations seperti yang pertama kali diadopsi pada tahun 1976

13 Lihat the UN Global Compact. Tersedia di www.unglobalcompact.org [diakses tanggal 25 Januari 2018].

${ }^{14}$ Carola Glinski, op. cit. hlm. 15-16

15 The OECD Guidelines for Multinational Enterprises dilampirkan ke dalam The OECD Declaration on International Investment and Multinational Enterprises yang diadopsi pertama kali pada tahun 1976.

${ }^{16}$ The Declaration yang diadopsi oleh ILO pada tahun 1998 menyampaikan bahwa semua anggota ILO memiliki kewajiban untuk menghormati, memajukan dan melaksanakan dengan itikad baik dan sesuai dengan konstitusi, prinsip-prinsip mengenai hak fundamental yang merupakan bagian dari Konvensi: (a) freedom of association and the effective recognition of the right to collective bargaining; (b) the elimination of all forms of forced or compulsory labour; (c) the effective abolition of child labor; and inisiatif dari berbagai stakeholders pada tahun 2000 dikeluarkan dan didukung oleh perusahaan-perusahaan swasta, berbagai negara, organisasi kemasyarakatan, organisasi serikat pekerja, serta beberapa agen PBB. ${ }^{17}$ John Ruggie dipilih sebagai Perwakilan Khusus Sekjen PBB pada bidang HAM dan Perusahaan transnasional serta bentuk perusahaan bisnis lainnya pada tahun 2005. ${ }^{18}$ John Ruggie membutuhkan waktu sekitar 6 tahun untuk melakukan penelitian dan konsultasi dari tahun 2005-2011, yang berkaitan dengan hubungan antara HAM dan Bisnis. ${ }^{19}$ John Ruggie sebagai perwakilan khusus Sekjen PBB, merancang sebuah "concept and policy framework' untuk mengatur hubungan antara bisnis dan human rights. ${ }^{20}$ Kemudian, ditambah adanya standard otoritatif internasional yang inovatif dalam bidang bisnis dan HAM yaitu UN Guiding Principles on Business and

(d) the elimination of discrimination in respect of employment and occupation.

${ }^{17}$ Stephanie Lagoutte. 2015. "New Challenges States within the Field of Human Rights and Business". Nordic Journal of Human Rights. 33 (2):158.

${ }^{18}$ Florian Werrstein. 2015. "Normativity, Ethics, and the UN Guiding Principles on Business and Human Rights: A Critical Assessment". Jounal of Human Rights.14 (2): 162.

${ }^{19}$ James Harrison. 2013. "Establishing A Meaningful Human Rights Due Diligence Process for Corporations: Learning from Experience of Human Rights Impact Assessment". Impact Assessment and Project Appraisal. 31 (2): 107.

${ }^{20}$ Jonathan Bonnitcha and Robert McCorquadale. 2017. "The Concept of "Due Diligence" in the UN Guiding Principles on Business and Human Rights". The European Journal of International Law. 28 (3): 899. 
Human Rights. ${ }^{21}$ Special Representative of the Secretary-General of the United Nations (SRSG) yang ditunjuk oleh UN Commission on Human Rights melalui resolusi 2005/69 telah menghasilkan the Framework dan UN Guiding Principles on Business and Human Rights selama 6 tahun mandat yang diberikan. 22 UN Guiding Principles dibuat kemudian untuk memastikan the Framework berjalan.

Bagian pertama dalam UN Guiding Principles yaitu state obligation. Sebagai bagian dari tanggung jawab negara, maka pemerintah harus menindaklanjuti Ruggie's Principles di tingkat nasional maupun internasional sebagai sebuah petunjuk bagi MNCs dalam beroperasi. Pada tingkat internasional, negara-negara dapat bekerjasama untuk mengimplementasikannya baik dalam perjanjian internasional yang bersifat bilateral ataupun multilateral. Selain itu, pembuatan kerangka kerja (framework) oleh pemerintah dapat menjadi bukti kuat bahwa pemerintah memiliki komitmen yang kuat dalam mengimplementasikan Ruggies' Principles di tingkat nasional. Dalam konteks Asia Tenggara, kawasan

\footnotetext{
${ }^{21}$ Alexandra Guaqueta. 2013. "Henessing Corporation: Lessons from the Voluntary Principles on Security and Human Rights in Colombia and Indonesia". Journal of Asian Public Policy. 6 (2): 130.

${ }^{22}$ Stephanie Bijlmakers. 2013. "Business and Human Rights Governance and Democratic Legitimacy: The UN "Protect, Respect and Remedy" Framework and the Guiding Principles". Innovation The European Journal of Social Science Research. 26 (3): 292.

dapat mengimplentasikan Ruggie's principles dalam sebuah kebijakan atau hukum pada level regional maupun berakhir pada pelaksanaan di level nasional. Meskipun Asia Tenggara termasuk kawasan yang tergolong telat untuk membicarakan HAM sejak terbentuknya Association of South East Asia Nations (ASEAN), tetapi harapan baru terhadap upaya untuk memajukan dan melindungi HAM mulai terlihat sejak lahirnya Piagam ASEAN pada tahun 2007. Harapan itu semakin mendekati kenyataan setelah terbentuknya badan HAM ASEAN pada tahun 2009 yang dinamakan ASEAN Intergornmental Commission on Human Rights (AICHR). Badan ini diharapkan mambu menjadi agen terdepan untuk memajukan dan melindungi HAM termasuk pelanggaran HAM yang berkaitan dengan aktivitas korporasi.

Artikel ini akan fokus mendiskusikan permasalahan bagaimana masyarakat internasional mengambil tindakan terhadap permasalahan bisnis dan HAM dan apa langkah-langkah yang dapat dilakukan oleh ASEAN untuk ikut membicarakan bisnis dan HAM di Asia Tenggara? Kerjasama internasional merupakan pintu yang mengawali proses beroperasi suatu MNCs dan proses awal pengimplementasian Ruggie's Principles di suatu negara. Sehingga kerjasama internasional menjadi sangat penting 
perannya untuk meningkatkan kepedulian korporasi dan pemerintah terhadap perlindungan HAM yang berkaitan dengan kegiatan bisnis. Artikel ini bertujuan untuk menunjukkan dan memahami tindakan apa saja yang telah diambil oleh masyarakat internasional untuk mengatur masalah bisnis dan HAM.

\section{Analisis dan Pembahasan}

A. Peran Kerjasama Internasional untuk Mengatur Masalah Bisnis dan HAM

Kewajiban negara untuk memberikan perlindungan terhadap pelanggaran HAM oleh pihak ketiga, pertanggungjawaban korporasi untuk menghormati HAM, dan penyediaan akses pemulihan bagi korban, tiga hal tersebut mejadi pillar penting dalam the Ruggie's Framework dan the Guiding Principles. ${ }^{23}$ Tetapi jika mengacu kepada 3 pillar tersebut, maka negara tetap menjadi subjek yang paling berperan penting dalam proses perlindungan HAM. Negara memiliki tanggungjawab untuk memastikan bahwa hukum nasionalnya telah mengatur tentang HAM serta harus bekerjasama dengan negara-negara lain untuk membuat hukum mengenai HAM di level internasional. Sedangkan korporasi mendapatkan sebagian tanggungjawab negara untuk

\footnotetext{
${ }^{23}$ Carola Glinski. op. cit. hlm. 17
}

menyediakan akses pemulihan bagi korban pelanggaran HAM sebagai bentuk nyata penghormatan terhadap HAM.

Peran klasik negara dalam
melindungi setiap individu dari
pelanggaran HAM yang dilakukan oleh
pihak ketiga (non-states actors) disebut
sebagai kewajiban negara untuk
melindungi yang dicantumkan di dalam
Pillar pertama UNGPs. Memastikan atau
mendorong korporasi bisnis agar tidak
melakukan pelanggaran HAM
merupakan kewajiban negara di dalam bidang HAM dan bisnis. Ketika sebuah negara tidak sanggup (unable) atau tidak niat (unwilling) untuk melindungi individu dari pelanggaran HAM baik yang dilakukan oleh MNCs atau korporasi lokal, maka hal ini negara memiliki tanggung jawab untuk bertindak. Pillar 3 UNDPs menegaskan peran negara dan pihak ketiga untuk menyediakan akses pemulihan bagi korban pelanggaran HAM. ${ }^{24}$

Setidaknya ada tiga persepsi yang memperkuat peran negara di dalam pemikiran HAM. Pertama, political discourse pada HAM telah dibentuk berdasarkan sejarah baik secara politik maupun instrument hukum HAM yang dimaksudkan untuk mencegah penyalahgunaan wewenang yang dilakukan oleh pemerintah. Kedua, legal

\footnotetext{
${ }^{24}$ Stephanie Lagoutte. op. cit. hlm. 160
} 
discourse pada HAM telah didorong oleh asumsi bahwa hanya negara yang memiliki personalitas hukum dan dengan demikian hanya negara yang dapat menjadi subjek hukum HAM internasional, sedangkan korporasi tidak demikian. Ketiga, di dalam normative discourse tentang tanggungjawab perusahaan, sebuah fokus yang agak filantropis dikombinasikan dengan kecenderungan untuk menyerahkan masalah hukum kepada ahli hukum yang membuat perdebatan HAM menjadi kabur. Hal tersebut dimaksudkan cenderung untuk mengurangi peran dominan negara di dalam HAM yang terlampau luas. Faktanya, memang gagasan corporate social responsibility (CSR) pada dasarnya bersifat sukarela di luar hukum, sampai saat ini konsep konvensional CSR tersebut telah diketahui (European Commission 2001; Commission of the European Communities 2006), hal tersebut kemudian menjadi penghambat pandangan bahwa HAM adalah kawajiban sebagai domain yang relevan bagi perusahaan. ${ }^{25}$

Peran non-states actor di era globalisasi merupakan keniscayaan, terutama jika dilihat dari perkembangan MNCs meningkat dengan pesat. Hal tersebut berdampak pada peran dan kekuatan negara yang semakin

\footnotetext{
${ }^{25}$ Florian Wettstein. op. cit. hlm. 164.
}

berkurang. Misalnya, di bidang HAM yang sebelumnya hanya negara yang diberikan tanggungjawab untuk menjamin perlindungannya, tetapi saat ini MNCs juga diberikan beban untuk ikut serta memperhatikan HAM. Meskipun demikian, negara tetap menjadi pusat perhatian dalam pelaksanaan HAM sebagai pembuat kebijakan. UNGPs mencantumkan 2 jenis kewajiban negara. Pertama, sebagai pengingat akan kewajiban HAM internasional yang dibuat oleh kerjasama negara-negara melalui perjanjian internasional maupun regional. Kedua, membuat sejumlah rekomendasi untuk mengambil tindakan yang dianggap penting, misalnya bahwa negara seharusnta proaktif untuk memastikan bahwa perusahaan yang beroperasi di wilayah yang terkena dampak konflik tidak terlibat pelanggaran HAM dengan mengatur kegiatan lintas territorial dari perusahaan-perusahaan yang berdomisili atau terdaftar di dalam yurisdiksinya. Dengan demikian, kewajiban negara untuk melindungi terdiri dari sebuah 'smart mix' antara lain hard law untuk mengingatkan bahwa negara memiliki kewajiban yang mengikat secara hukum, dan komitmen negara di dalam soft law. ${ }^{26}$

Ada beberapa regulasi yang berbicara mengenai bisnis dan HAM yang lahir melalui kerjasama antar

\footnotetext{
${ }^{26}$ Stephanie Lagoutte. loc.cit.
} 
negara sebelum UNGPs dan Ruggie' Principles dibuat. Meskipun aturan-aturan yang ada masih bersifat soft law dan dianggap gagal dalam mengcover

permasalahan-permasalahan bisnis dan HAM. Tetapi, upaya-upaya tersebut dapat dijadiin bukti bahwa negara telah berusaha untuk menjalankan fungsi sebagai duty bearer HAM yang utama.

a) The OECD Guidelines

The OECD ${ }^{27}$ adalah organisasi regional yang pertama (geopolically) untuk mengatur permasalahan pertanggungjawaban korporasi di level internasional. OECD membuat sebuah Declaration on International Investment and Multinational Enterprises ${ }^{28}$ pada tahun 1976 dan salah satu lampirannya

${ }^{27}$ The OECD's origins date back to 1960, when 18 European countries plus the United States and Canada joined forces to create an organization dedicated to economic development. Today, our 35 Member countries span the globe, from North and South America to Europe and Asia-Pacific. They include many of the world's most advanced countries but also emerging countries like Mexico, Chile and Turkey. the OECD has since expanded its membership to include Japan, Australia, New Zealand, Finland, Mexico, Korea and four former communist states in Europe: the Czech Republic. Hungary, Poland and the Slovak Republic. Non-members can also subscribe to OECD agreements and treaties. There are currently about 70 non-member countries including Brazil, China, and many others from the least developed countries in Africa and elsewhere. Lihat $\mathrm{di}$ http://www.oecd.org/about/membersandpartners. [diakses tanggal 25 Januari 2018].

28 Deklarasi ini diadobsi pada tahun 1976. TNCs disyaratkan untuk mematuhi Guidelines di manapun mereka beroperasi. Pemerintah juga diwajibkan untuk melaksanakan prinsip national treatment kepada perusahaan asing, untuk memperkuat kerjasama dalam investasi asing berskala internasional, dan untuk menghindari dan mengurangi penggunaan persyaratan yang bertentangan dengan MNCs. adalah OECD Guidelines. ${ }^{29}$ Guidelines ini sebuah framework yang mekanismenya tidak mengikat, soft law untuk membantu menegakkan etika perilaku MNCs. Pendekatan yan bersifat non- binding dan soft law, karena maksud dari pedoman tersebut bukan untuk mengatur, tetapi seperti namanya yaitu untuk mengarahkan (pedoman). Standar OECD Guidelines ini hanya terbatas pada negara di mana MNCs beroperasi dan tidak berlaku bagi negara-negara di luar anggota OECD. 30

The OECD Guidelines merupakan sekumpulan rekomendasi yang meliputi prinsip-prinsip dan standar-standar good practices ditujukan kepada MNCs oleh negara-negara anggota. ${ }^{31} \mathrm{Hal}-\mathrm{hal}$ yang diatur di dalam prinsip-prinsip OECD, seperti keterbukaan informasi, penyuapan, kepentingan konsumen, sains, teknologi, lingkungan, pekerja, dan persaingan serta pajak. The Guidelines, sejak diadopsi pada tahun 1976 telah mengalami beberapa kali revisi. Namun, proses review yang membawa perubahan yang sangat signifikan dilakukan pada tahun 2000. ${ }^{32}$ Perubahan yang sangat relevan dilakukan pada proses review tahun 2000 adalah diperkenalkannya sebuah ketentuan

\footnotetext{
${ }^{29}$ Danwood Mzikenge Chirwa. op. cit. hlm. 81.

${ }^{30}$ K. A. Reinert, et al. op. cit. hlm. 818.

${ }^{31}$ Paragraf I(I) OECD Guidelines for Multinational Enterprises: Revision 2000.

${ }^{32}$ Danwood Mzikenge Chirwa. op. cit. hlm. 82.
} 
yang menegaskan bawah korporasi harus 'menghormati HAM yang diakibatkan oleh kegiatan MNCs sesuai dengan kewajiban dan komitmen dari negara di mana MNCs beroperasi. ${ }^{33}$ Ketentuan ini menunjukkan bahwa perusahaan diharapkan untuk mematuhi kewajiban HAM internasional, regional dan domestic di negara tempat mereka beroperasi. Sebisa mungkin negara pihak dapat mendorong MNCs untuk menghormati HAM, tidak hanya yang berkaitan dengan karyawan, tetapi juga orang lain yang terkena dampak dari kegiatan mereka. ${ }^{34}$ Oleh karena itu, MNCs seyogiayanya juga menghormati segala aturan internasional dan hukum nasional tentang HAM. Sehingga MNCs dalam beroperasi dapat menyeimbangkan kepentingan HAM baik hak sipil dan politik maupun hak ekonomi, social dan budaya.

Perubahan OECD Guidelines terbaru dilakukan pada tahun 2011, dan sifatnya masih sebagai "recommendations" dan "non-binding principles and starndards" serta telah diadopsi oleh 45 negara. Meskipun Guidelines tahun 2011 ini tidak mengikat MNCs, tetapi negara-negara yang melekat dengan MNCs tersebut membuat sebuah "binding commitment

${ }^{33}$ Part II (2) OECD Guidelines for Multinational Enterprises: Revision 2000.

${ }^{34}$ The Working Party on the OECD Guidelines for Multinational Enterprises the OECD Guidelines for Multinational Enterprises: Text, Commentary and Clarifications (2001) 12.

115 to implement them". Dengan demikian, Guidelines tersebut hanya mengikat negara, tetapi tidak bagi MNCs. ${ }^{35}$ Maka mekanisme adalah bagaimana negara dapat membuat kebijakan ataupun legislasi yang dapat mempengaruhi perilaku korporasi yang ramah HAM.

The Guidelines pada tahun 2000 mengatur MNCs untuk "Respect the human rights of those affected by their activities consistent with the host government's international obligation and commitments." Kemudian hal tersebut diubah menjadi "Respect the internationally recognized human rights of those affected by their activities." Perubahan yang dilakukan di dalam Guidelines tahun 2011 ini telah mengurangi ambiguitas versi sebelumnya yang mencakup semua jenis HAM yang diakui secara universal. Hal lain yang muncul atas perubahan pada tahun 2011 yaitu "risk based due diligence procedure" untuk mengindentifikasi dan perbaikan pelanggaran HAM. ${ }^{36}$ Konsekuensi positif yang muncul dari pembaharuan tersebut adalah bahwa Guidelines tidak hanya sebatas upaya preventif tetapi lebih maju dengan adanya upaya pemulihan terhadap korban pelanggaran HAM.

b) The International Labour Organization (ILO) Tripartite Declaration Instrumen internasional kedua

\footnotetext{
${ }^{35}$ K. A. Reinert, et al. loc. cit.

${ }^{36}$ Ibid.
} 
yang berkaitan dengan bisnis dan HAM adalah the ILO Tripartite Declaration yang diharapkan bisa menjadi solusi terhadap permasalahan pertanggungjawab korporasi terhadap HAM. Pembuatan instrumen ini sekiranya dapat diadopsi oleh negara-negara sebagai acuan dalam membuat hukum nasionlanya masing-masing. Alasan the International Labour Organization untuk membuat instrument ini adalah isu tenaga kerja yang paling membutuhkan perhatian tinggi bagi korporasi di dalam hubunganya dengan negara tuan rumah di tahun 1960-1970an. Proses pembuatan instrument ini membutuhkan tiga kali pertemuan sampai pada akhirnya disepakati pada saat pertemuan working group dalam skala kecil pada tahun 1977. Keputusan dari working group tersebut diterima oleh ILO's Governing Body pada November 1977 sebagai the ILO's Tripartite Declaration of Principles Concerning Multinational Enterprises. ${ }^{37}$ Pertama dimulai dengan pertemuan tripartite para ahli pada Oktober-November 1972 tentang "Relationship between multinational corporations and social policy'. Setelah itu, dilakukan follow up meeting yang diadakan pad Mei 1976. ${ }^{38}$

\footnotetext{
${ }^{37}$ Lihat ILO, “Triparte Declaration History”. Tersedia di

http://www.ilo.org/public/english/employment/multi /history.htm [diakses tanggal 25 Januari 2018].

${ }^{38}$ Danwood Mzikenge Chirwa. op. cit. hlm. 86.
}

Mendorong MNCs untuk berkontribusi positif dalam upaya memajukan ekonomi social, dan untuk meminimalisir serta mengatasi dampak negatif yang bisa muncul dari kegiatan MNCs adalah dua tujuan utama dari deklarasi ini. 39 Instrumen ini berisi tentang prinsip-prinsip dan hak-hak yang berkaitan dengan promosi pekerjaan, kesempatan dan perlakuan yang sama, keamanan kerja, pelatihan, gaji, keuntungan dan kondisi kerja, keselamatan dan kesehatan. 40 Prinsip-prinsip tersebut ditujukan kepada pemerintah, pekerja, serikat pekerja di negara pengirim maupun negara penerima, serta bagi MNCs sendiri. ${ }^{41}$ Meskipun deklarasi ini lebih fokus kepada hak pekerja, tetapi instrumen ini juga terdiri dari prinsip-prinsip penting yang berkaitan dengan penerapan hak-hak yang lain bagi TNCs. ${ }^{42}$

Deklarasi ini setidaknya berbeda dengan the OECD Guidelines, UNGPS, yang tidak membicarakan kewajiban non-state actors untuk menghormati HAM secara spesifik, tetapi the ILO Tripartite Declaration ini mendorong agar non-state actors menghormati UDHR, International Covenant on Civil and Political Rights (ICCPR) dan the International Covenant on Economic, Social and Guidelines Rights

\footnotetext{
${ }^{39}$ Lihat paragraph 2.

${ }^{40}$ Danwood Mzikenge Chirwa. op. cit. hlm. 87.

${ }^{41}$ Lihat paragraph 4 ILO Tripartite Declaration.

${ }^{42}$ Danwood Mzikenge Chirwa. loc. cit.
} 
(ICESCR)..$^{43} \mathrm{Hal}$ di atas mengindikasikan bahwa deklarasi ini menganjurkan agar para pihak tidak hanya mementingkan kedaulatan negara, hukum dan regulasi nasional, tetapi menghormati juga standar internasional yang berhubungan.

c) The UN Global Compact

Sebuah inisiatif yang berbasis voluntary untuk pengembangan, pelaksanaan dan pembagian tanggungjawab serta kebijakan korporasi yang berkelanjutan dikeluarkan pada bulan Juli tahun 2000 yang disebut the UN Global Compact (UNGC). ${ }^{44}$ UNGC merupakan inisiatif pertama yang didorong oleh PBB kepada MNCs setelah kegagalan UN Code. The Compact tersebut diusulkan oleh Sekjen Kofi Annan pada the World Economic Forum yang diadakan di Davos, Swiss pada tanggal 31 Januari 1999.45

The Global Compact ini tidak dimaksudkan sebagai alat yang berbentuk regulasi melainkan sebuah inisatif suka rela dari MNCs dalam bentuk akuntabilitas publik, transparansi dan keterbukaan untuk melengkapi aturan yang ada dan membuat inovasi serta tindakan yang kolektif di lapangan. ${ }^{46}$ Selain UNGC ini hanya bersifat sukarela, dalam arti tidak mengikat secara hukum dalam

${ }^{43}$ Ibid .

44 J.R.M. Wetzel. 2016. Human Rights in Transnational Business. Switzerland: Springer International Publishing. hlm. 149.

${ }^{45}$ Danwood Mzikenge Chirwa. op. cit. hlm. 89.

${ }^{46}$ J.R.M. Wetzel. loc. cit. pengertian hukum positif, tetapi inisiatif ini memiliki kekuatan normative yang cukup besar. Setidaknya inisitif ini mampu membuat standar yang diharapkan dapat menjadi acuan bagaimana seharusnya MNCs berperilaku. Dengan demikian, UNGC ini tidak hanya mempengaruhi kinerja korporasi yang berbasis HAM, tetapi juga dapat mempengaruhi kondisi normative negara setempat. 47 Meningkat partnership dan akuntabilitas sesuai dengan konsep Global Compact dapat menunjukkan kesediaan korporasi untuk membangun hubungan langsung dengan stakeholders dan untuk memikul tanggung jawab, khususnya perlindungan HAM.

Empat mekanisme yang harus dijalankan untuk mencapai tujuan Global Compact ini. Pertama, dialog kebijakan yang dipelopori oleh UNGC yang dilakukan yang dilakukan setahun sekali untuk memfasilitasi "kesepahaman dan upaya bersama diantara bisnis, pekerja dan NGOs dalam menghadapi tantangan globaisasi”. Kedua, mendorong korporasi untuk membuat laporan yang berkaitan dengan praktek bisnisnya dan selanjutnya dibagikan ke pihak yang lain. Ketiga, UNGC memfasilitasi jaringan lokal pada tingkat internasional, regional, dan lokal untuk memastikan bahwa prinsip-prinsip yang relevan

\footnotetext{
${ }^{47}$ Stephanie Bijlmakers. op. cit. hlm. 288.
} 
disosialisasikan dan diterapkan secara luas. Keempat, mendukung proyek yang berbasis partnership antara perusahaan, UN Agencies serta organisasi kemasyarakatan yang ikut terlibat dalam memastikan bahwa negara-negara ikut memenuhi tujuan PBB. ${ }^{48}$ Jika mengacu kepada empat mekanisme di atas, maka UNGC dapat membuat dampak yang signifikan terhadap regulasi perusahaan di bidang HAM, karena hal tersebut menunjukkan bahwa perusahaan harus bertanggung jawab atas pelanggaran HAM yang melibatkan atau dipengaruhi oleh korporasi. ${ }^{49}$

Uraian ketiga bentuk kebijakan ataupun regulasi yang membicarakan HAM dan bisnis di atas menunjukkan bahwa terdapat persamaan dari segi sifatnya yaitu voluntary. Ketiganya masuk dalam kategori soft law yang tidak mengikat secara hukum. Soft law dapat dikategorikan sebagai hukum internasional karena pembentukannya berdasarkan kesepakatan negara-negara berdaulat, sedangkan di sisi yang lain itu juga dikategorikan sebagai non-hukum karena tidak memiliki kekuatan mengikat. ${ }^{50}$ Meskipun demikian, dalam konteks HAM dan bisnis mereka dapat dijadikan sebagai acuan

\footnotetext{
${ }^{48}$ Danwood Mzikenge Chirwa. op. cit. hlm. 90.

49 J.R.M. Wetzel. loc. cit.

${ }^{50}$ Muhammad Insan Tarigan. 2016. Penguatan Peran ASEAN Intergovernmental Commission on Human Rights (AICHR) dalam Upaya Perlindungan Hak-Hak Pekerja Migran di ASEAN. Tesis pada FH UGM. Yogyakarta. hlm. 89.
}

bagi negara-negara dan korporasi untuk melengkapi aturan dan hukum dalam prakteknya masing-masing.

Persamaan lainnya adalah instrumen yang telah dijelaskan di atas, semuanya tercipta tidak lepas dari peran kerjasama internasional. Dalam hal ini, PBB dan ILO yang merupakan organisasi internasional sebagai wadah bagi negara-negara berdaulat untuk melakukan perundingan serta mengambil keputusan yang dianggap bermanfaat bagi masyarakat dunia. Maka tidak salah jika pembicaraan HAM dan bisnis menjadi hal yang penting saat ini merupakan pengaruh dari kerjasama antar negara pada level internasional. Salah satu bentuk upaya yang paling anyar pada level internasional yang memperhatikan HAM dan bisnis adalah UN Principles dan Ruggie's Framework. Kerjasama internasional menjadi kunci penting dalam proses implementasi UN Principles dan Ruggie's Framework, mulai dari pembentukan hingga pada tahap sosialisasi serta meresap ke dalam hukum domestik suatu negara maupun ke dalam peraturan internal sebuah korporasi.

\section{B. Bisnis dan HAM di Asia Tenggara}

Isu HAM dan bisnis merupakan dua bidang yang saat ini menjadi topik utama dan banyak dibicarakan di wilayah Asia Tenggara. Semangat atas perlindungan HAM di Asia Tenggara mulai menjadi nyata, hal ini terlihat 
melalui the Cha-am Hua Hin Declaration on the Inauguration of the AICHR pada pertemuan Konfrensi Tingkat Tinggi (KTT) ASEAN 15 di Thailand yang berlangsung pada 23 Oktober 2009. Tonggak sejarah perkembangan HAM di ASEAN dengan ditetapkannya sebuah badan HAM di tingkatan ASEAN yang disebut sebagai ASEAN Intergovernmental Commission on Human Right (AICHR) atau Komisi Antar Pemerintah ASEAN untuk HAM, selanjutnya disebut Badan HAM ASEAN. 51 Pembicaraan isu HAM ini sebenarnya dimulai saat diadopsinya Piagam ASEAN pada bulan November 2007. ASEAN telah mengambil langkah yang sangat positif terhadap pembicaraan HAM ke depan.

Upaya peningkatan kegiatan bisnis di Asia Tenggara dapat di lihat melalui KTT ASEAN ke-9 di Bali tahun 2003, para pemimpin ASEAN sepakat membentuk Masyarakat Ekonomi ASEAN (MEA) yang ditargetkan tercapai pada 2020. Dalam ketetapan Bali Concord II, ASEAN Economic Community adalah salah satu dari tiga pilar yang saling berkaitan yang menjadi landasan untuk terbentuknya ASEAN Community. Keputusan petinggi pada KTT ASEAN ke-12 di Cebu, Januari, 2007 adalah mempercepat jadwal

\footnotetext{
${ }^{51}$ Herman Kraft. 2012. "RtoP by Increments: The AICHR and Localizing the Responsibility to Protect in Southeast Asia. The Pacific Review. 25 (1): 24.

119
}

pembentukan ASEAN Community dari target semula tahun 2020 menjadi tahun 2015. Percepatan ini dimaksudkan para petinggi ASEAN untuk mengantisipasi situasi persaingan ekonomi yang semakin tajam, adanya kekhawatiran bahwa Asia Tenggara akan tertinggal jauh dari pesatnya pertumbuhan ekonomi China dan India. ${ }^{52}$ Mekipun sebelum ini, ASEAN telah berusaha untuk mengembangkan kerjasama ekonomi regional yang lebih konfrehensif yang dipengaruhi juga oleh perkembangan ekonomi internasional yang begitu pesat. ${ }^{53}$ Upaya yang dimaksud adalah pembentukan ASEAN Free Trade Area (AFTA) yang dicapai melalui KTT ASEAN di Singapura bulan Januari, 1992. 54 Tetapi, MEA ini merupakan bentuk baru dan lebih serius untuk meningkatkan kemajuan negara-negara Asia Tenggara melalui kegiatan bisnis yang lebih terstruktur. MEA ini setidaknya dapat membentuk iklim yang memungkinkan untuk melakukan kegiatan bisnis yng lebih dinamis, melalui: ${ }^{55}$

52 C.P.F. Luhulima, dkk. 2008. Masyarakat Asia Tenggara Menuju Komunitas ASEAN 2015. Yogyakarta: Pustaka Pelajar. hlm. 109.

${ }^{53}$ Bambang Cipto. 2007. Hubungan Internasional di Asia Tenggara (Teropong Terhadap Dinamika, Realitas, dan Masa Depan). Yogyakarta: Pustaka Pelajar. hlm. 245-246.

54 Ade Maman Suherman. 2003. Organisasi Internasional dan Integrasi Ekonomi Regional dalam Persfektif Hukum Dan Globalisasi. Jakarta: Ghalia Indonesia. hlm. 152.

${ }^{55}$ Ibid. 
1. Arus perdagangan yang dapat berkembang dengan semakin mengurangi hambatan-hambatan baik berupa tarif maupun hambatan non-tariff yang masih cukup banyak.

2. Kebebasan arus modal baik dalam bentuk direct investment, investasi partfolio, pinjaman komersial maupun bantuan finansial multilateral tanpa hambatan administratif atau hambatan lainnya yang berlebihan.

3. Kebebasan arus migrasi tenaga kerja, baik tingkat buruh maupun tingkat tenaga ahli tanpa resistensi yang berlebihan dari pihak sindikat buruh di negara maju yang memprotes adanya pendatang baru maupun relokasi usaha tdari negara maju ke negara berkembang.

4. Kebebasan teknologi tanpa hambatan.

Bisnis dan HAM merupakan dua bidang yang menjadi fokus pembahasan di Asia Tenggara pada saat ini. Pada bidang HAM, ASEAN masih harus melakukan review untuk memperkuat perlindungan dan pemajuan HAM. Di bidang bisnis, ASEAN juga masih perlu melakukan perundingan dan meningkatkan daya saing kawasan terhadap negara-negara yang sedang berkembang pesat, seperti India, China, Jepang, dll. Salah satu yang pasti terjadi dalam rangka mendukung pejalanan MEA adalah penanaman modal asing. $\mathrm{Hal}$ ini tentunya menjadi tugas ASEAN untuk menjaga MNCs yang menanamkan modalnya memiliki akuntabilitas dan memiliki komitmen terhadap HAM. Kondisi demikian tentunya terbuka kesempatan bagi ASEAN untuk membicarakan serta membuat kebijakan yang berkaitan dengan bisnis dan HAM. AICHR dalam hal ini dapat dijadikan pemeran utama dalam upaya mengimplementasikan UNGPs di wilayah Asia Tenggara dengan mengintergrasikan kebijakan di level internasional, regional serta strategi nasional.

European Union (EU) telah terlebih dahulu menunjukkan komitmennya terhadap bisnis dan HAM melalui "Conclusions on Business and Human Rights" pada bulan Juni 2016. ${ }^{56}$ Kebijakan yang diambil oleh EU tersebut dilakukan tepat pada usia yang ke 5 tahun UNGPs. Dukungan dan niat EU terhadap UNGPs dapat dilihat melalui Council Conclusions on Business and Human Rights untuk memulai EU Action Plan on Responsible Business Conduct harus mampu meresap kepada seluruh kerangka kebijakan di Eropa untuk meningkatkan implementasi UNGPS. Dewan EU menegaskan di dalam Conclusions-nya bahwa "EU Member States have taken the lead internationally on developing and adopting National

\footnotetext{
56 Daniel Augenstein, et. al. 2018. "The UNGPs in the European Union: The Open Coordination of Business and Human Rights?" Business and Human Rights Journal. 3 (1): 1.
} 
Action Plans to implement the Guiding Principles or integrating [them] into national [Corporate Social Responsibility (CSR)] Strategies". 57 Berdasarkan catatan Dewan tersebut negara-negara anggota EU harus ikut berperan penting mengimplementasikan UNGPs secara internasional maupun nasional.

Conclusion's yang dikeluarkan Dewan EU tersebut telah berdampak pada proses implementasi UNGPs yang dilakukan berdasarkan UN Working Group tentang pedoman National Action Plan (NAP). Sampai saat ini ada 8 (delapan) anggot EU yang telah mengeluarkan NAPs tentang bisnis and HAM (Inggris, Belanda, Denmark, Finlandia, Lithuania, Swedia, Italia dan Jerman) dan 8 (delapan) negara anggota lainnya telah membuat draft atau rencana inisiasi sebuah proses NAP (Republik Ceko, Prancis, Yunani, Irlandia, Latvia, Portugal, Slovenia dan Spanyol). ${ }^{58}$ Berdasarkan yang telah dilakukan oleh negara-negara anggota EU tersebut, maka EU dapat disebut sebagai garda terdepan dalam upaya mengimplementasikan UNGPs melalui proses NAP.

ASEAN melalui AICHR tentunya dapat melakukan hal yang sama dengan EU, tetapi dapat dilakukan dengan cara yang berbeda pula sesuai dengan kebutuhan dan kondisi tertentu. Isu-isu

57 Ibid.

58 Ibid. hlm. 3. tentang HAM memang pastinya menjadi tanggung jawab AICHR sebagai badan HAM di Asia Tenggara. AICHR dapat mengeluarkan kebijakan-kebijakan untuk ikut berperan dalam mengimplementasikan UNGPs sesuai dengan kewenangan yang dimilikinya. Term of Reference (ToR) AICHR yang memberi mandat untuk bekerja merupakan acuan dasar untuk membicarakan UNGPs lebih luas di wilayah Asia Tenggara. Mungkin ada beberapa hal yang dapat dilakukan oleh AICHR dari 14 mandat yang telah dimilikinya, adalah sebagai berikut:

1. Meningkatkan perhatian publik terhadap isu bisnis dan HAM;

2. Mendorong negara-negara anggota untuk mengambil tindakan yang efektif untuk mengimplementasikan UNGPS;

3. Melaksanakan dialog dan konsultasi dengan organ-organ ASEAN, organisasi kemasyarakatan, dan stakeholder yang lain;

4. Membuat instrument hukum yang mengikat.

AICHR diberikan mandat untuk meningkatkan perhatian publik tentang HAM dengan berbagai cara, misalnya melalui pendidikan, penelitian, dan sosialisasi kebijakan HAM. Akademisi, peneliti dan aktivis HAM memiliki peran yang sangat vital dan bekerjasama untuk mengidentifikasi potensi pelanggaran HAM dari aktivitas bisnis di Asia 
Tenggara. Selain itu, kepentingan untuk menganalisis perlindungan yang dilakukan oleh negara-negara anggota terhadap korban pelanggaran HAM yang berkaitan dengan bisnis, termasuk upaya pemulihan korban tersebut. Kemudian hal di atas ditulis dalam sebuah laporan untuk diberikan kepada badan-badan HAM yang ada, misalnya pada kegiatan UN Human Rights Council's Universal Periodic Review, ${ }^{59}$ badan HAM ASEAN atau badan HAM lainnya baik di level internasional, regional atau nasional. Selain itu, organisasi kemasyarakatan juga dibutuhkan untuk melakukan sosialisasi segal informasi yang dianggap penting untuk diketahui public tentang kebijakan bisnis dan HAM.

AICHR juga harus dapat mendorong negara-negara anggota untuk mengambil tindakan yang efektif untuk mengimplementasikan UNGPs di Asia Tenggara. Negara-negara anggota ASEAN dapat melakukan National Action Plan (NAP) seperti yang telah dilakukan oleh negara-negara di Eropa, di mana hal ini juga merupakan mandat yang ada di dalam UNGPs. Hasil dari NAP setiap negara kemudian didiskusikan di dalam pertemuan antar negara yang difasilitasi oleh AICHR sebagai upaya untuk merefleksikan isu bisnis dan HAM di negara

59 Universal Periodic Review ini merupakan mekanisme yang menerima semua negara anggota untuk berdikusi dan menyerahkan laporan yang berkaitan dengan HAM, setiap 4 tahun sekali. masing-masing. Setiap negara anggota dapat saling bertukar informasi, bertukar instrument hukum dan kebijakan masing-masing. Pertemuan ini pada akhirnya diharapkan mampu untuk menemukan bentuk good practices yang dilakukan negara-negara anggota di dalam menangani isu bisnis dan HAM serta upaya mengimplementasikan UNGPs. Pertemuan tersebut akan lebih bermanfaat ketika negara-negara anggota berdasarkan hasil dari NAP masing-masing negara dapat melakukan harmonisasi hukum tentang bisnis dan HAM, sehingga di Asia Tenggara dapat memiliki satu standard hukum tentang bisnis dan HAM. Hal ini penting dan bermanfat bagi negara-negara anggota untuk membuat atau membangunan hukum nasionalnya tentang bisnis dan HAM. Hasil NAP masing-masing negara penting untuk dilaporkan kepada AICHR, mengingat bahwa badan HAM ASEAN tersebut tidak miliki kewenangan untuk melakukan monitoring langsung ke masing-masing negara.

Selain melakukan diskusi dengan negara anggota, AICHR juga dapat melakukan dialog dan konsultasi dengan pihak-pihak yang dapat memberikan kontribusinya terhadap pemajuan perlindungan HAM, termasuk isu bisnis dan HAM. AICHR perlu melakukan dialog dengan organ-organ ASEAN lainnya, karena permasalahan HAM ini tidak bisa terlepas dari 
bidang-bidang lainnya, baik politik, ekonomi, social, dan kebudayaan. AICHR juga butuh masukan dari organisasi kemasyarakatan dibidang HAM berkaitan dengan upaya untuk membentuk dan meningkatkan kebijakan perlindungan bisnis dan HAM. TNCs yang beropreasi di wilayah Asia Tenggaran juga perlu untuk diajak berdiskusi untuk meningkatkan komitmen atas perlindungan HAM yang berkaitan dengan kegiatan bisnis. Melakukan dialog dan konsultasi dengan entitas-entitas lain juga telah diamanatkan di dalam Pasal V Piagam ASEAN.

Berdasarkan hal-hal yang telah dijabarkan di atas, semuanya dapat disebut sebagai kajian literatur, karena AICHR hanya menerima laporan dan masukan dari entitas lain. Meskipun demikian, hasil-hasil kajian literatur baik dalam bentuk laporan penelitian, laporan hasil NAP dari masing-masing negara dan hasil dialog dengan beberapa stakeholders tersebut dapat dijadikan bahan dasar untuk membentuk instrument hukum yang mengikat. Study-study litertur dapat dijadikan sebagai bahan dasar untuk membangun konsep rule of law dan good governance

\section{Bibliografi}

\section{Buku:}

Ade Maman Suherman. 2003. Organisasi Internasional dan dan bagaimana hal itu berhubungan dengan penghormatan dan perlindungan HAM yang berkaitan dengan bisnis.

\section{Penutup}

Kerjasama internasional menjadi kunci penting dalam proses pembentukan dan implementasi instrument hukum internasional tentang bisnis dan HAM, seperti the OECD Guidelines, the ILO Triparte Declaration, dan the UN Global Compact, serta UN Principles dan Ruggie's Framework. Meskipun instrument hukum yang ada masih sebatas aturan yang bersifat soft law. Asia Tenggara melalui AICHR dapat melakukan beberapa langkah untuk memajukan perlindungan HAM yang berkaitan dengan aktivitas bisnis seperti yang tertuang di dalam UNGPs dan Ruggie's principles. AICHR dapat melakukan study literature untuk meningkatkan perhatian publik, mendorong negara-negara anggota untuk mengambil tindakan yang efektif, melaksanakan dialog dan konsultasi dengan organ-organ ASEAN, organisasi kemasyarakatan, dan stakeholder yang lain serta membuat instrumen hukum yang mengikat tentang bisnis dan HAM.

Integrasi Ekonomi Regional dalam Persfektif Hukum Dan Globalisasi. Jakarta: Ghalia Indonesia. , 2014. Hukum Perdagangan Internasional: Lembaga 
Penyelesaian Sengketa WTO dan

Negara Berkembang. Jakarta:

Sinar Grafika

Bambang Cipto. 2007. Hubungan

Internasional di Asia Tenggara

(Teropong Terhadap Dinamika,

Realitas, dan Masa Depan).

Yogyakarta: Pustaka Pelajar.

C.P.F. Luhulima, dkk. 2008. Masyarakat

Asia Tenggara Menuju Komunitas

ASEAN 2015. Yogyakarta: Pustaka

Pelajar.

J.R.M. Wetzel. 2016. Human Rights in Transnational

Business.

Switzerland: Springer International

Publishing.

Jurnal:

Alexandra Guaqueta. 2013. "Henessing Corporation: Lessons from the Voluntary Principles on Security and Human Rights in Colombia and Indonesia". Journal of Asian Public Policy. 6 (2).

Carola Glinski. 2017. "The Ruggie Framwork, Business Human Rights Self-Regulation and Torts Law: Increasing Standards through Mutual Impact and Learning". Nordic Journal of Human Rights. 35 (1).

Daniel Augenstein, et. al. 2018. "The UNGPs in the European Union: The Open Coordination of Business and Human Rights?". Business and Human Rights Journal, 3 (1).
Danwood Mzikenge Chirwa. 2017. "The Long March to Binding Obligations Transnational Corporations in International Human Rights Law". South African Journal on Human Rights. 22 (1).

Florian Werrstein. 2015. "Normativity, Ethics, and the UN Guiding Principles on Business and Human Rights: A Critical Assessment".Journal of Human Rights. 14 (2).

Geordan Graetz and Daniel M. Franks, 2013. "Incorporating Human Rights into the Corporate Domain: Due Dilligence, Impact Assessment and Integrated Risk Management". Impact Assesment and Project Apparsial, 31 (2).

Herman Kraft, 2012. "RtoP by Increments: the AICHR and Localizing the Responsibility to Protect in Southeast Asia". The Pacific Review. 25 (1).

Imam Prihandono. 2011. "Transnational Corporations and Human Rights: Strengthening Current Tools to Promote Accountability". Transnational Corporations Review. 3 (3).

James Harrison. 2013. "Establishing A Meaningful Human Rights Due Diligence Process for Corporations: Learning from Experience of Human Rights Impact Assessment" Impact 
Assessment and Project Appraisal. 31 (2).

Jonathan Bonnitcha and Robert McCorquadale. 2017. "The Concept of "Due Diligence" in the UN Guiding Principles on Business and Human Rights". The European Journal of International Law. 28 (3). Kenneth A. Reinert, et al. 2016. "The New OECD Guidelines for Multinational Enterprises: Better but Not Enough". Development in Practice. 26 (6).

Stephanie Bijlmakers. 2013. "Business and Human Rights Governance and Democratic Legitimacy: the UN "Protect, Respect and Remedy" Framework and the Guiding Principles". Innovation: The European Journal of Social Science Research, Vol. 26 (3).

Stephanie Lagoutte, 2015. "New Challenges States within the Field of Human Rights and Business". Nordic Journal of Human Rights.
33 (2).

Tesis:

Muhammad Insan Tarigan. 2016. Penguatan Peran ASEAN Intergovernmental Commission oh Human Rights (AICHR) dalam Upaya Perlindungan Hak-Hak Pekerja Mlgran di ASEAN, Tesis pada FH UGM. Yogyakarta.

\section{Internet:}

ILO 'Triparte Declaration History. Tersedia pada http://www.ilo.org/public/english/e mployment/multi/history.htm [diakses tanggal 25 Januari 2018]. http://www.oecd.org/about/membersand partners [diakses tanggal 25 Januari 2018].

The UN Global Compact. Tersedia pada www.unglobalcompact.org [diakses tanggal 25 Januari 2018]. 